\title{
COMMISSION 14: ATOMIC AND MOLECULAR DATA (DONNÉS ATOMIQUES \& MOLÉCULAIRES)
}

\author{
PRESIDENT: Sveneric Johansson \\ VICE-PRESIDENT: Steven R. Federman \\ SECRETARY: Glenn Wahlgren \\ ORGANIZING COMMITTEE: Saul J.Adelman, Emile Biémont, Steven \\ R. Federman, Sveneric Johansson, Jim Lawler, Michael Mickelson, Don- \\ ald C. Morton, Tanya Ryabchikova, Peter L. Smith, Chantal Stehle, Glenn \\ Wahlgren
}

\section{Business meeting of IAU Commission 14}

Present: S. R. Federman, W. C. Martin, D. C. Morton, W. H. Parkinson, A. Pradhan, P. L. Smith (Chair).

Smith called attention to Joint Discussion 17 on Atomic Data for X-Ray Astronomy, which Commission 14 proposed and sponsored, and thanked Anil Pradhan for his work as Chair of the SOC. [Note added later: More than 50 people signed the attendees list for JD17; typical attendance at each session was 40 to 50 people.]

Smith also called attention to Joint Discussions 20 (Frontiers of High Resolution Spectroscopy) and 21 (Astrochemistry of External Galaxies), which were co-sponsored by Commission 14, and to the Invited Discourse by E. van Dishoeck, an active member of Commission 14, on From Molecules to Planets: a Milky Way Dreaming.

Smith thanked the Chairs of the Working Groups for the effort that went into preparing the Working Group Reports. This 39-page document, which has summaries of new data and new publications that discuss atomic and molecular data of relevance to astronomy, is available from the Commission web page. After the announcement, Smith chaired the meeting in place of the absent Johansson.

Officers: Because there was only one candidate for each office, there was no election. The Chair announced that the new officers are those listed above.

Organizing Committee: Our commission's usual practice is for a member to serve on the Organizing Committee (OC) for six years, with past Presidents serving for three years past their term as President and other officers serving longer than six years if necessary to complete their service as officers. Thus, K. A. Berrington, N. Feautrier, and F. Rostas completed their terms, and were thanked by Smith. The new Organizing Committee is listed above.

Working Groups: Smith reported that G. Wahlgren would replace W. Wiese as Chair of WG-2, and that J. H. Black would replace E. van Dishoeck as Chair of WG-5. Smith apologized for the lack of Chairs and/or Co-Chairs for WG-5, -7 , and -8 . The list of new Chairs and Co-Chairs is given on the next page.

Members: Smith reported that the Commission has about 175 nominal members, but that the OC has no idea about the number that are active users or producers of atomic or molecular data for astronomy. In an attempt, motivated by a request from the IAU 
Executive Committee, e-mail was sent to about 120 members (e-mail addresses are not available for the other 55 ). Of the 120 , there were 20 bad addresses and only 18 replies (about $50 \%$ of the latter were from the OC).

Meetings of Commission Presidents and By-law Changes: The first Meeting of Commission Presidents started with a request for help with updating of the IAU mailing list, especially the addition of e-mail addresses. There was also discussion of inactive members - there doesn't seem to be a policy nor a method for getting people to resign (members are appointed by their National Committees, and are members for life).

New Statutes and By-Laws were discussed. Among other things, they disenfranchise individual members of the IAU (all votes are now by the National Representatives), move Commission 14 to a new Division XII (Union World Wide Activities), and put stricter controls on Commissions and their OC's and WG's. New Statutes and By-Laws were approved, essentially unanimously and without public discussion, by the General Assembly on 15 July. The goals are easier/quicker creation and elimination of commissions and working groups, and there were promises the new rules would, "facilitate change, not enforce it". Nevertheless, Smith urged the new officers of Commission 14 to closely monitor the impact of the new rules on Commission activities.

Federman attended the second Meeting of Commission Presidents where discussion of updating e-mail lists was again discussed.

Closing Remarks: In closing, Smith regretted that more people were not in attendance. It is impossible, he pointed out, to make decisions on Chairs and Co-Chairs when less than $5 \%$ of the membership participates in meetings and only about $10 \%$ respond to e-mail. He urged the new officers and OC to try to remedy the communication problem, and offered to help. He hoped that more astronomers who use atomic and molecular data could be encouraged to join Commission 14, that efforts be made to ensure that all relevant topics were covered by the WG's, and that more members be involved in Commission activities.

\section{Working Groups:}

1. Atomic Spectra \& Wavelengths

2. Atomic Transition Probabilities

3. Collision Processes

4. Line broadening

5. Molecular Structure

6. Molecular Reactions on Solid Surfaces

7. Optical Properties of Solids

8. Gas Phase Reactions
Chair

Co-Chair

S. JOHANSSON

G. WAHLGREN

D. R. SCHULTZ

C. STEHLE

J. H. BLACK

W. SCHUTTE

t.b.d.

T. J. MILLAR
G. NAVE

J. R. FUHR

P.C. STANCIL

G. PEACH

t.b.d.

L. d'HENDECOURT

t.b.d.

t.b.d.

Peter L. Smith and Steven R. Federman Past President of the Commission and Vice-President 2003-2006, respectively 